\title{
PReS-FINAL-1007: Regulatory T cells functional specialization in jia
}

\author{
G Mijnheer*, B Prakken, FV Wijk \\ From 20th Pediatric Rheumatology European Society (PReS) Congress \\ Ljubljana, Slovenia. 25-29 September 2013
}

\section{Introduction}

Regulatory $\mathrm{T}$ cells (Treg) are important players in keeping the immune system in balance. In juvenile idiopathic arthritis (JIA), an autoimmune disease characterized by chronic inflammation of the joints, this balance is disturbed. Recently, different functional subsets of regulatory $\mathrm{T}$ cells (Treg) have been described in mice and human that mirror the T helper subsets. A lot remains unknown about the function and mechanism of action of Treg (subsets), especially in inflammatory environments.

\section{Objectives}

In our study we aim to investigate the adaptability of regulatory $\mathrm{T}$ cells based on phenotype and function. In particular, our focus is on Treg derived from different inflammatory environments.

\section{Methods}

Treg will be isolated from peripheral blood and synovial fluid of JIA patients and peripheral blood of healthy controls and analyzed based on the expression of chemokine receptors CXCR3, CCR6 and CCR4. Currently, autologous suppression assays, allogenic $\mathrm{T}$ cell suppression assays and monocyte suppression assays are performed with these Treg subsets derived from different environments.

\section{Results}

Treg subsets that mirror Th subsets can be found and discriminated based on there chemokine receptor profile (i.e. CXCR3, CCR6 and CCR4) in peripheral blood of healthy control and JIA patients, and in the synovial fluid of JIA patients.

Pediatric Immunology, UMC Utrecht, Utrecht, The Netherlands

\section{Conclusion}

Different subsets of Treg can be identified in the synovial fluid of JIA patients. This allows us to further look in to Treg subset function.

\section{Disclosure of interest}

None declared.

Published: 5 December 2013
Submit your next manuscript to BioMed Central and take full advantage of:

- Convenient online submission

- Thorough peer review

- No space constraints or color figure charges

- Immediate publication on acceptance

- Inclusion in PubMed, CAS, Scopus and Google Scholar

- Research which is freely available for redistribution 